ヒト外尿道括約筋筋電図の定量解析

Automatic Decomposition Electromyography を用いた自動解析

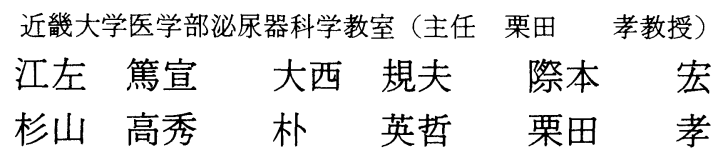

\title{
QUANTITATIVE ELECTROMYOGRAPHIC ANALYSIS OF THE EXTERNAL URETHRAL SPHINCTER USING AUTOMATIC DECOMPOSITION ELECTROMYOGRAPHY ON NORMAL SUBJECTS
}

\author{
Atsunobu Esa, Norio Oonishi, Hiro Kiwamoto, Takahide Sugiyama, \\ Young-Chol Park and Takashi Kurita \\ Department of Urology, Kinki University School of Medicine \\ (Director: Prof. T. Kurita)
}

Motor unit action potentials (MUPs) of the external urethral sphincter muscle during cystometry were analysed on six normal males. Electrodes were of consentric needle type having the exposed tip surface of $0.07 \mathrm{~mm}^{2}$, and the potential changes were analysed by automatic decomposition electromyography (ADEMG), for isolation and characterization of unit discharges. Number of analysed units was as follows: Two at rest, 4 at first desire to void, and 6 at maximum desire to void. Number of the recorded units and the firing rate were increased along with the degree of bladder filling. Average MUP figures as follows: Amplitude of $206 \mu \mathrm{V}, 8.3 \mathrm{msec}$. duration, and $5.4 \mathrm{~Hz}$ firing rate at rest; $246 \mu \mathrm{V}$, $9.7 \mathrm{msec}$ and $7.3 \mathrm{~Hz}$ at first desire to void; $277 \mu \mathrm{V} .9 .7 \mathrm{msec}$ and $7.2 \mathrm{~Hz}$ at maximum desire to void, respectively. It is concluded that external urethral sphincter maintains its urinary continence by excitation of the neuromuscular units, and by the increase in the firing rate of individual MUP during bladder filling.

Key words: external urethral sphincter, quantitative electromyography, cystometry

\begin{abstract}
要旨：健常者（volunteer）6 例を対象に，膀胱内压測定を用いた膀腅の充満における外尿道括約筇筋電 図の変化を Automatic decomposition electromyography（ADEMG）を用いて定量解析した。膀腌内 圧測定は媒体として炭酸ガス $(100 \mathrm{ml} / \mathrm{min})$ を使用し，筋電図針は同芯針電極 $\left(0.07 \mathrm{~mm}^{2}\right)$ を使用した。 放電する運動単位活動電位 (MUP)は膀胱空虚時から出現し, 膀胱の充満に伴ってその数と個々の MUP の発射頻度は有意に増加した. MUP の振幅, 持続時間, 発射頻度の平均值は膀胱空虚時, 初発尿意時, 最大尿意時でそれぞれ $206 \mu \mathrm{V}, 8.3 \mathrm{msec}, 5.4 \mathrm{~Hz}, 246 \mu \mathrm{V}, 9.7 \mathrm{msec}, 7.3 \mathrm{~Hz}, 277 \mu \mathrm{V}, 9.7 \mathrm{msec}, 7.2 \mathrm{~Hz}$ であった，外尿道括約笳による尿の禁制は神経筋単位の興奮により保持され，参加する MUP の増加と 個々の MUP の発射頻度の増加に基いていた。 また ADEMGは迅速な筇電図定量解析が可能であり, 今 後外尿道括約筋筋電図法の一手段になると考兄られた。
\end{abstract}

キーワード：外尿道括約筋，筋電図，膀脱内圧測定

緒 言

排尿の動態機能を検討するらえで，外尿道括約筋の 筋電図検査は欠くことのできない検査法の一つであ
る.しかしその多くは膀胱内圧測定や尿流量測定と同 時に記録されるものであり，電位の検討と排尿筋との 協調状態を観察しているにすぎない，筋電図本来の意 
味にもどれば筋電図は神経筋単位 (Neuromuscular unit 以下 NMU) の活動電位（Motor unit action potential 以下 MUP) によって構成されるもので, NMU の各レベルの病変により，それぞれ対応する所 見が得られる。これらの変化を客観的に, 迅速に解析 することができれば，筋電図検査はさらに臨床診断上 有用になると考えられる。従来, MUP の解析は写真 フィルム上で手動操作により, パラメーターを定量的 に計測されてきたが，この方法は時間を要するだけで なく，検査者の主観的判断が入ることが多いとされて きた1). 近年，これらの欠点を補らため，コンピュー ターにより筋電図波形をデジタル化し, 解析する試み が盛んになってきた。今回, 健常者を対象に膀脱内圧 測定時に打ける外尿道括約筋筋電図を, Nicolet 社の Automatic decomposition electromyography (ADEMG)を用いて定量解析し, 膀胖充満にともなう MUP の数, 振幅, 持続時間, 発射頻度の変化を検討し た.

\section{対象および方法}

排尿障害を有さない健常男子（volunteer）6例（上 部尿路結石症 4 例, 膀胼腫瘍 1 例, 包茎 1 例）を対象 とし，患者の同意を得たらえで検査を行った。年齢は 19歳～55歳，平均 33.3 歳であった。被験者を砕石位と 乙，筋電図針を直腸内示指誘導下に会陰部正中約 $1 \mathrm{~cm}$ 外側から前立腺尖部に向け刺入した。刺入部位は筋電 計のスピーカーからの特有の音で確認した。次いで被
験者を仰臥位とし8Fr 4 孔式カテーテルを経尿道的に 膀胱へ挿入した。この際筇電図針のずれが生じた場合, 再度刺入部位を補正した。膀胱内圧は直腸内圧と同時 に測定し，媒体としては炭酸ガスを用いた。

膀脱空虚時の安静状態(REST) で外尿道括約筋筋電 因の活動を 10 秒間導出し，その間に出現するMUPの パラメーター（数・振幅 $\mathrm{AMP}$ ・持続時間 DUR・発射 頻度 FR）を測定した。

次いで膀胱内に炭酸ガスを $100 \mathrm{ml} / \mathrm{min}$ の速度で注 入し, 注入開始から初発尿意出現までの間, 初発尿意 出現時 (FDV), 初発尿意出現時から最大尿意出現まで の間, 最大尿意出現時 (MDV), 最大尿意出現後, 排 尿反射出現時に同様に各々外尿道括約筋筋電図の活動 を10秒間導出し，その間に出現する MUPのパラメー ターの測定結果を経時的に比較した。筋電図針は同芯 針電極 $\left(0.07 \mathrm{~mm}^{2}\right.$ record area, $40 \mathrm{~mm}$ long, $0.5 \mathrm{~mm}$ diameter)を用いた。筋電計は Nicolet 社製 Viking 筋 電計を用い, 雑音は high-pass filter $10 \mathrm{~Hz}$, low-pass filter $5 \mathrm{kHz}$ でカットした。振幅はピークからピークま でを測定し， $100 \mu \mathrm{V}$ 以下のものは削除した。持続時間 の計測にあたっては感度を $100 \mu \mathrm{V} / \mathrm{div}$, 速度を $5 \mathrm{msec} /$ $\mathrm{cm}$ に設定し, 基線より最初のフレから基線への最終 的復帰までの時間を測定した ${ }^{2)}$. 位相数が 4 種以上の ものを多相性電位とした．有意差検定は $\mathrm{t}$ 検定を用い た.

Fig. 1 ADEMG analysis on an external urethral sphincter at the maximum desire to void recorded on a 21-old-year man. Detailed explanations see the text.

INS* 2.05

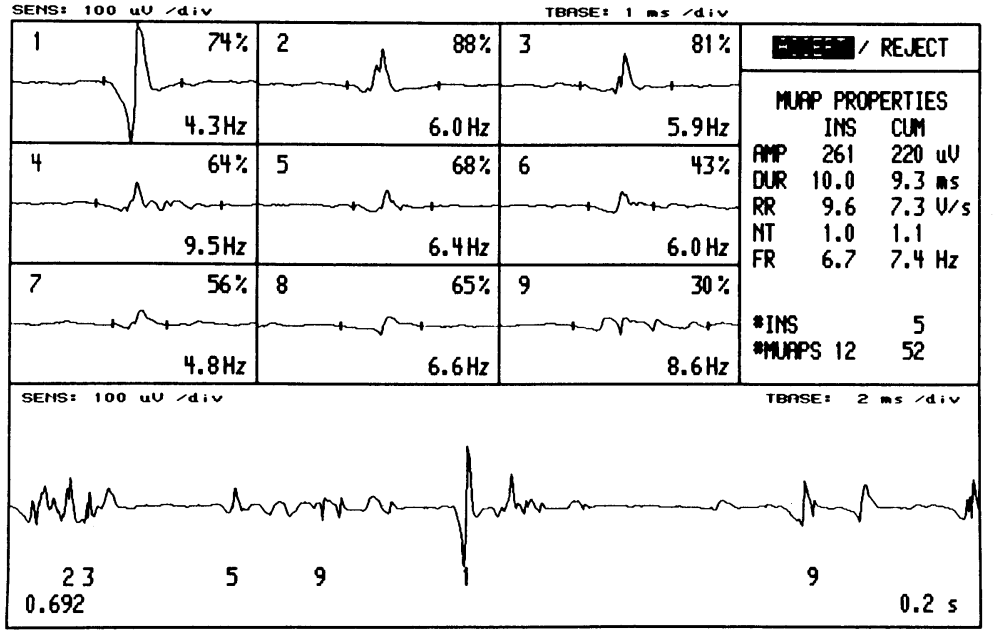




\section{結果}

膀胱内压測定の結果は正常型で排尿反射を認め，筋 電図上排尿筋括約筋協調不全は認めなかった。膀脱内 圧測定時の各時期で導出された MUP は筋電計のブラ ウン管上に Fig. 1のように表示される.

1. 膀胼内圧測定における MUP の出現とその変化 代表例として55歳膀脱腫瘍の症例を提示する. 膀脱 内圧測定の結果 (Fig. 2) と各時期で記録した MUPを 経時的に示した（Fig. 3).

本症例の場合, 安静時には MUP が同定されなかっ たが, 膀胱注入量の増加に伴い, MUP の出現数が増加 し，一度出現したMUPは最大尿意出現後まで持続的 に出現した。膀胼内圧測定中各時期で測定した各々の MUP の振幅・持続時間・発射頻度の变化を示した (Fig. 4). 振幅は MUPによって増加するものもあれ ば低下するものもありばらつきがみられた。

持続時間はいずれの時期に扔いても比較的安定した
測定結果を示した。発射頻度はいずれの MUP も膀脱 内注入量の増加に伴い増加した。

健常者 6 例の膀胱内圧測定中における MUP 数の変 化をFig. 5 に示した。安静時に解析した 6 例において MUP が認められたのは 5 例で， 2 例は 1 種類， 1 例は 3 種類， 1 例は 4 種類の MUP が出現した。全例膀胱 内注入量の増加に伴いMUP の出現数は増加し, 初発 尿意出現時に比べて最大尿意出現時において解析でき た MUP は増加していた（1 例は安静時のみの解析で あった).これらの MUP は排尿反射出現時には全て消 失した。

\section{MUPのパラメーターの変化}

各症例の膀脱内圧測定各時期で出現した MUP の振 幅，発射頻度の動きをFig. 6,7 に示した. 振幅の平均 值は最大尿意出現時まではほとんど増加も低下も認め なかったが, 最大尿意時以降に増加する傾向にあった。 発射頻度の平均値は膀胼内注入量の増加に伴い増加す

Fig. 2 An ADEMG record of external urethral sphincter and of cystometry on a 55-year-old man. Analysis was carried out in each 10 second-epoch during the bladder filling. Details refer the METHODS.

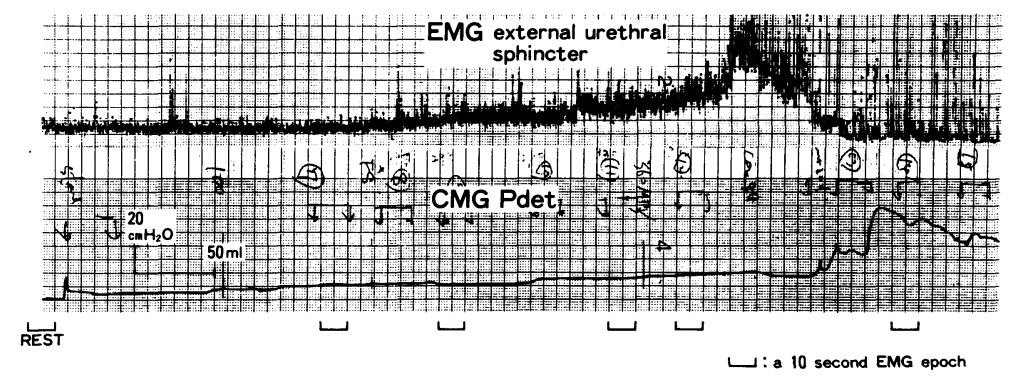

Fig. 3 Examples of MUPs of external urethral sphincter displayed in relation to the level of the bladder filling. MUPs presented in a column were recorded on the same unit. Note the sequential change of the potential pattern in relation to the bladder volume.

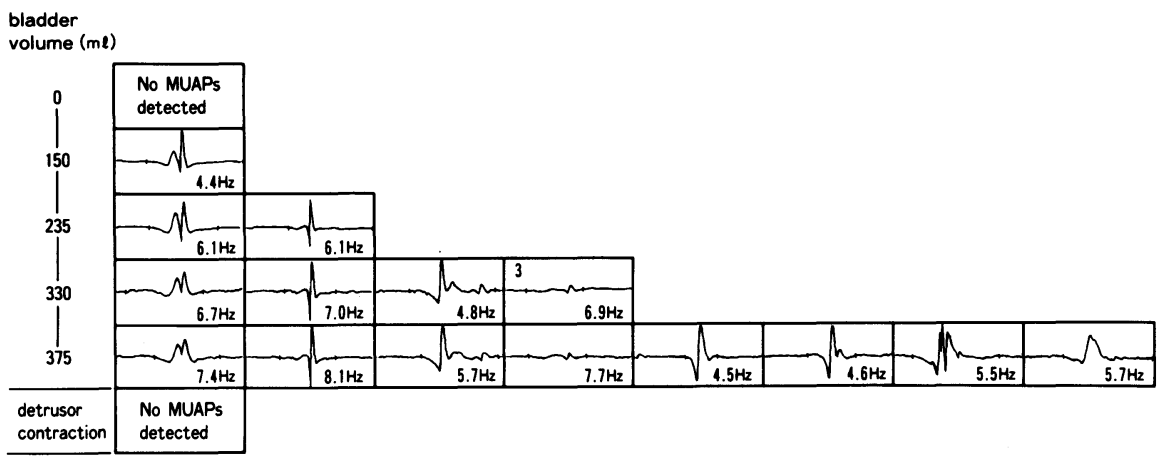


Fig. 4 Changes in the amplitude, the duration and the firing rate of individual MUP during the bladder filling. FDV : first desire to void. MDV : maximum desire to void.

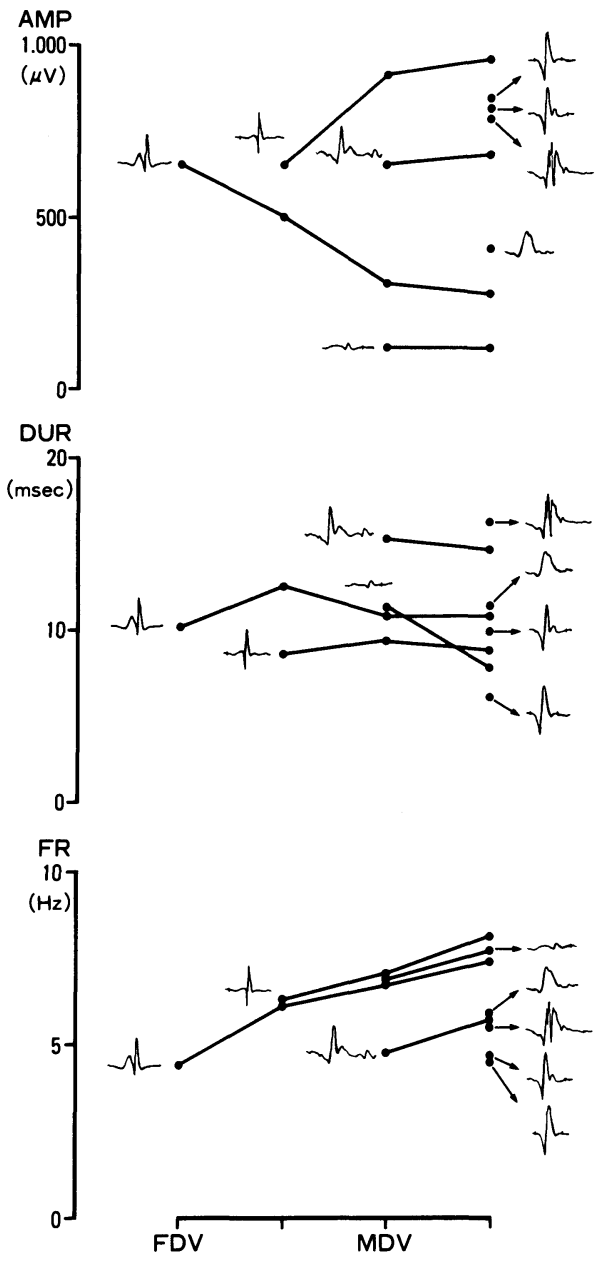

Fig. 5 Increase in the number of MUPs during bladder filling recorded on 6 normal subjects. Abbreviations refer the legend in Fig. 3.
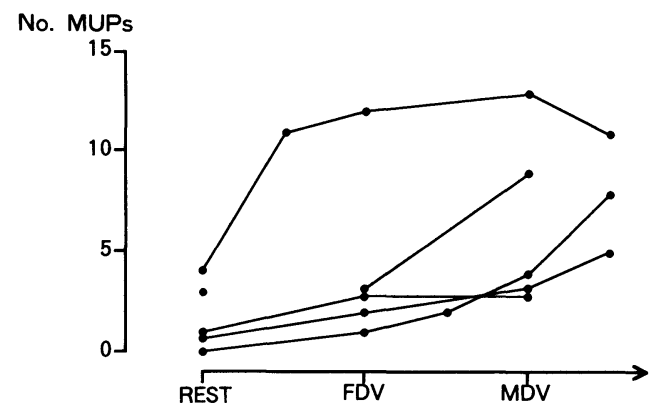

Fig. 6 Mean amplitude changes in MUPs during bladder filling recorded on 6 normal subjects.

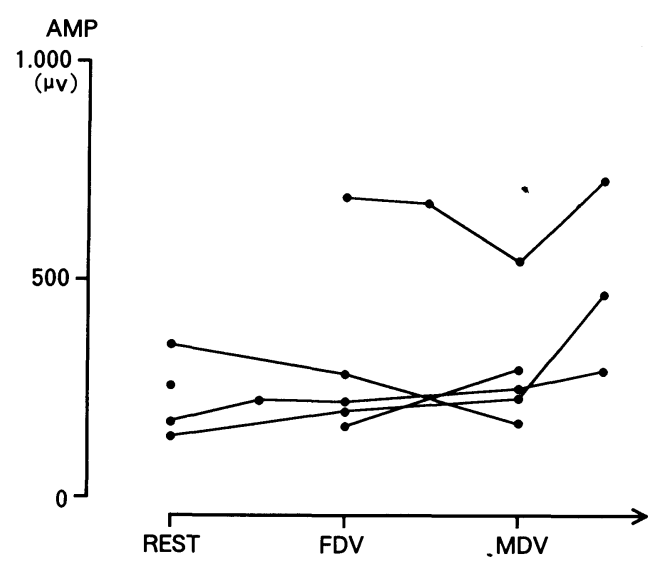

Fig. 7 Mean firing rate changes in MUPs during bladder filling recorded on 6 normal subjects.

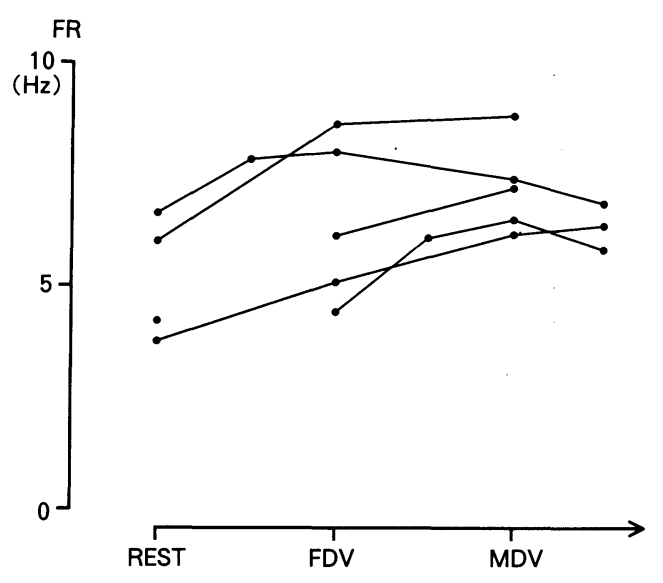

る傾向にあった。

Table 1 に各症例の膀胱内圧測定各時期で出現した MUP の振幅, 持続時間, 発射頻度の平均値を安静時, 初発尿意時, 最大尿意時の 3 群別に供覧した。持続時 間については ADEMGによる自動解析値と生波形か らの手動による解析値とを比較した (Fig. 8). 振幅の 平均值は安静時, 初発尿意時, 最大尿意時で有意な差 はなかったが，振幅の最大值は各時期でそれぞれ373 $\mu \mathrm{V}, 770 \mu \mathrm{V}, 987 \mu \mathrm{V}$ であった。持続時間の平均值も安 静時, 初発尿意時, 最大尿意時間で自動解析值, 手動 解析値ともに有意な差はなく, また各時期の自動解析 值，手動解析値間でも有意な差はなかった。持続時間 の各時期でのヒストグラムでは $3.8 \mathrm{msec}$ から $20 \mathrm{msec}$ 
Table 1 Statistical analysis. Mean values and standard errors for the amplitude, the duration and the firing rate of MUPs at rest, first desire to void and maximum desire to void, respectively, on 6 normal subjects.

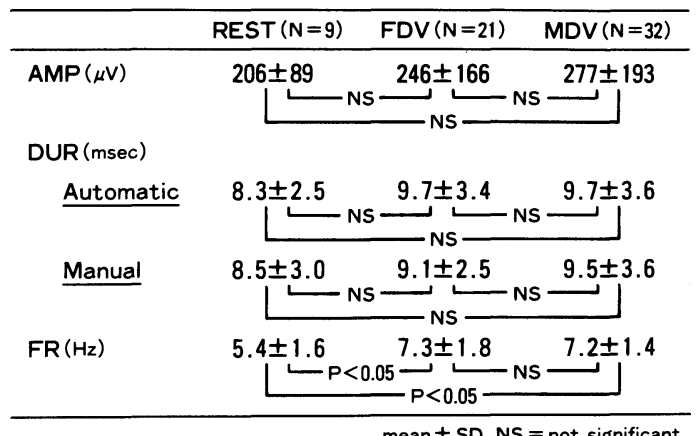

Fig. 8 Correlative relationship between ADEMG and manual measurement on the duration in 76 MUPs.

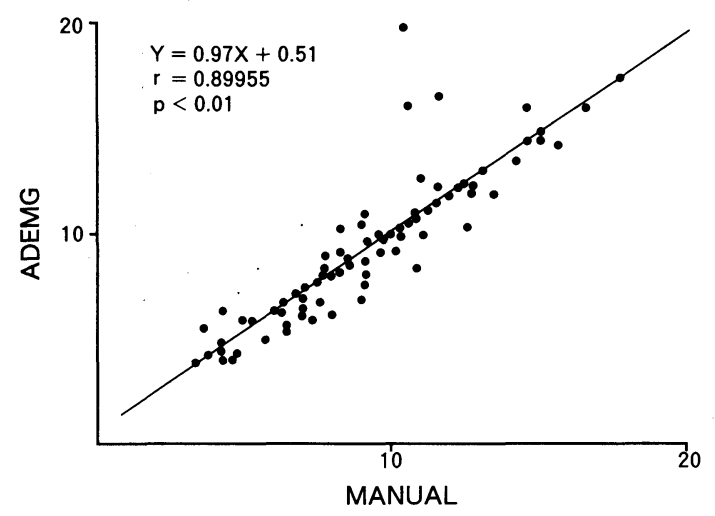

まで広範囲に分布がみられたが $8 \mathrm{msec} か ら 10 \mathrm{msec}$ での MUPが最も多く認められた（Fig. 9). 多相性電
位の出現率は安静時, 初発尿意時, 最大尿意時の各時

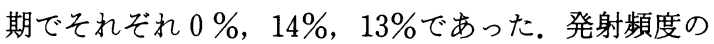
平均值は安静時に比べて初発尿意時, 最大尿意時で有 意の増加が認められた。

\section{考察}

外尿道括約筇を支配する下位運動ニューロンは第 2 〜 4 仙髄前角に位置する Onuf 核に細胞体を有し, 神 経支配は古典的に陰部神経とされているが3)4), 末梢で は副交感神経・交感神経も関与しているとの報告もあ り異論が多い4). 排尿の生理において膀胱の充満に よっておこる外尿道括約筋の緊張と膀胱の収縮時にお けるとの緊張解除は Barringtonの第 5 反射として有 名であり ${ }^{6)}$, 蓄尿期の尿の禁制維持に外尿道括約筋が 関与していることは周知の事実である。外尿道括約筋 は他の横紋筋と同様に遅筋と速筋によって構成されて おり,これらはそれぞれ生化学的・組織化学的に Type 1 fiber, Type 2 fiber であることが証明されている7). 外尿道括約筋の活動が膀胱の充満の程度に関係してい ることは知られており ${ }^{8)}$, 今回我々は膀脱空虚時, 膀胱 充満時にどのような MUPが活動をしているかを定量 的に解析した。

従来, 筋電図の定量解析はオシロスコープから撮影 した写真フィルム上から手動的に行われてきたが，膨 大な時間を要するだけでなく検者の主観的判断が入る とされてさだ1).さらに干渉波形の解析は非常に困難 であった。それらの欠点を補らために最新のコン ピューター技術の発達に伴い自動プログラムが開発さ れてきた。今回使用した ADEMG sostem もその一つ であり，その有用性は認められている9 .このシステム の概念の詳細は McGill ら ${ }^{10)}$ の文献にゆずるが，簡単 に，1）棘波のデジタル化，2）棘波の整列と分類，3） 棘波の規則性の確認，4）認識したMUPの加算平均 化，の 4 つのプロセスからなる. 同システムは生波形

Fig. 9 Histograms of the MUP duration distributions at rest, at first desire to void, and at maximum desire to void in 6 normal subjects. Details refer the RESULTS.
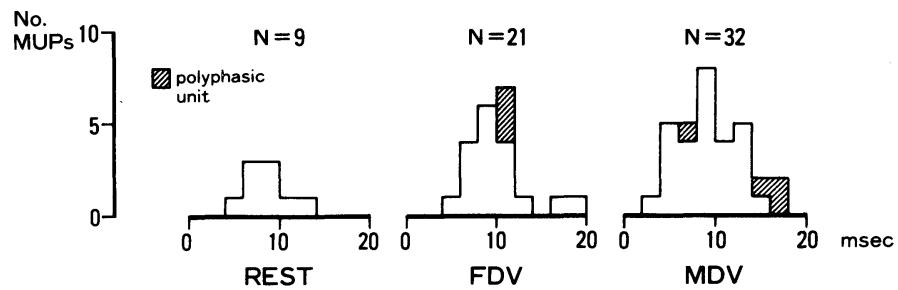
を表示することが可能であるため, 解析した76MUPs の持続時間について, ADEMG の結果と手動による測 定結果とを比較した (Fig. 8). 両者の結果に相関は認 められたが手動測定值に比べて自動測定値が高い MUP が少数であるが存在した。これは同システムが MUP の随伴電位を含めて計測したためであり，この ような MUPについては検者自身による補正の必要性 がある。

過去に外尿道括約筋の MUP を定量的に解析した報 告は測定条件や測定方法に違いはあれいくつか存在す る。振幅に関してはその平均値は $500 \mu \mathrm{V}$ 以下であると の報告が多(11) 13). 我々の結果では安静時, 初発尿意 時, 最大尿意時でそれぞれ $206 \pm 89 \mu \mathrm{V}, 246 \pm 166 \mu \mathrm{V}$, $277 \pm 193 \mu \mathrm{V}$ であり，その值は Fanciullacci ら ${ }^{13)}$ の報 告した最大随意収縮時の $256.1 \pm 7.12 \mu \mathrm{V}$ に類似して いた，筋電図針と筋線維との距離に余り関係なく安定 しているとされる持続時間について比較するとVereecken ら ${ }^{11}$ は $5.69 \pm 1.73 \mathrm{msec}$, Sadanori ら ${ }^{12)}$ $5.5 \pm 0.1 \mathrm{msec}$, Fowler $ら^{14)}$ は2.8msec, Fanciullacci $ら^{13)}$ は3.73 $\pm 0.07 \mathrm{msec}$ と述べており,安静時 $8.3 \pm 2.5$ $\mathrm{msec}$, 初発尿意時 $9.7 \pm 3.4 \mathrm{msec}$, 最大尿意時 $9.7 \pm 3.6$ msecであった結果と大きな差が認められた。この原 因は ADEMGによる自動解析では加算平均化された MUP からの測定であることと, 補正をする際は MUP の波形をモニタ一上に拡大して計測したためと考学ら れる。多相性電位は末梢性運動神経が不完全にブロッ クされた時や，筋内を走る神経分枝に部分的病変があ る場合に出現するといわれているが，正常笳からの記 録中にも 4 相以上の多相性電位は約 $10 \%$ に認められる とされている ${ }^{15)}$. 今回の検討では初発尿意時に $14 \%$, 最 大尿意時に $13 \%$ の多相性電位が認められたが，Davis ら ${ }^{16)}$ も最大尿意時に $10 \sim 15 \%$ 以上の多相性電位が出現 すると報告しており，会陰部刺入という電極針が不安 定になりやすい記録条件を考光ると約 $15 \%$ の多相性電 位の出現は病的な意義はもたないと考兄られる。

膀胼の充満によってもたらされる外尿道括約筋に対 する刺激を膀胼内圧測定によって定量化し，外尿道括 約筋筋電図の個々の MUP を経時的に検討したのは初 めてである。この検討で明らかになった事実は，健常 者では外尿道括約筋は膀胱の空虚時とか尿意の出現し ない蓄尿の始めから MUP が存在し, 膀胼の充満とか 尿意の出現とともに新たな MUP が出現し, それら 個々の MUP は蓄尿中消失することなく活動していた ことである。また個々の MUP は膀胖の充満とともに
発射頻度が増加していった. Fig. 1 は21歳男性の最大 尿意時に出現した全 MUPを示すが，No.1の MUP は最大尿意に達するまで出現しなかった MUPであ り, 他の MUPに比較してその振幅は大きく発射頻度

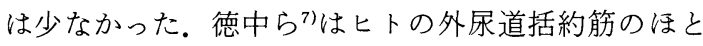
んどは遅筋線維である Type 1 fiber であるが, 速筋線 維である Type $2 \mathrm{~A}, 2 \mathrm{~B}$ fiber も存在していることを証 明しており，この症例のように最大尿意以後に出現す る緩慢ではあるが大きな振幅を有する新たな MUPは Type 2A，2B fiber の活動であり，それまでに活動す る MUP は Type 1 fiber の活動ではないかと推察す る.

本装置は筋電図の記録保存が可能であり, 被検者の 時間的負担が少なく, 従来莫大な時間を要した個々の MUP の振幅, 持続時間, 発射頻度, 位相数の定量解析 が迅速に評価できるだけでなく, 生波形も一時的に記 憶するため再評価が可能である。膀脱充満時における 外尿道括約筋筋電図にも十分応用可能であり, 今後病 的状態でのこれらパラメータを計測し，外尿道括約筋 筋電図法の診断的有用性について検討したい.

\section{結語}

健常者を対象に膀脱内圧測定を用いて蓄尿期におけ る外尿道括約筋筋電図の活動を定量的に解析した。

1）外尿道括約筋の活動は膀胼空虚時からみられ, 尿 意の出現にかかわらず膀胱容量の増加に伴いMUP の 数が増加し, 個々の MUPの発射頻度は増加した。

2) 最大尿意時を過ぎると新たに振幅の大きい, 持続 時間の長いMUP が出現した。

3）ADEMG system は筋電図波形の迅速かつ正確 な定量解析が可能であり，今後筋電図解析の有用な手 段になると考えられる。

本論文の要旨は第30回神経因性膀胱研究会, 第39回日本 泌尿器科学会中部総会に扮いて報告した.

\section{文献}

1）藤原哲司：筋電図の自動分析. 筋電図マニュアル, 第 1版，p. 40-46，金芳堂，京都， 1985.

2) Stalberg, A., Andreassen, S., Falk, B., Lang, H., Rosenfalck, A. and Trojaborg, W.: Quantitative analysis of individual motor unit potentials: A proposition for standardized terminology and criteria for measurement. J. Clin. Neurophysiol., 3, 313-348, 1986.

3) Fletcher, T.F. and Bradley, W.E.: Neuroamatomy of the bladder-urethra. J. Urol., 119, 153-160, 1978.

4) Gosling, J.: The structure of the bladder and 
urethra in relation to function. Urol. Clin. North. Am., 6, 31-38, 1979.

5) Elbadawi, A. and Schenk, E.A. : A new theory of the innervation of bladder musculature. Part 4. Innervation of the vesicourethral junction and external urethral sphincter. J. Urol., 111, 613-615, 1974.

6) Kuru, M.: Nervous control of micturition. Physiol. Rev., 45, 425-494, 1965.

7）徳中荘平, 藤井敬三, 岡村兼晴, 宮田昌伸, 金子茂 男, 八竹 直: 七上外尿道括約筋の生化学的研究. 日泌尿会誌, 79, 539-546, 1988.

8) Dibenedetto, M. and Yalla, S.V. : Electrodiagnosis of striated urethral sphincter dysfunction. J. Urol., 122, 361-365, 1979.

9) McGill, K.C. and Dorfman, L.J.: Automatic decomposition electromyography (ADEMG) : Validation and normative deta in brachial biceps. Electroencephalogr. Clin. Neurophysiol., 61, 453-461, 1985.

10) McGill, K.C., Cummins, K.L. and Dorfman, L.J. : Automatic decomposition of the clinical electromyogram. I.E.E.E. Trans. Biomed. Eng., BME-32, 470-477, 1985.

11) Vereecken, R.L., Derluyn, J. and Verduyn, H. : Electromyography of the perineal striated muscles during cystometry. Urol. Int., 30, 92-98,
1975.

12) Abe, S., Kawabe, K., Niijima, T. and Shimada, Y.: Electromyography of the external urethral sphincter in patients with prostatic hyperplasia. J. Urol., 132, 510-512, 1984.

13) Fanciullacci, F., Kokodoko, A., Garavaglia, P. F., Galli, M., Sandri, S. and Zanolo, A.: Comparative study of the motor unit potentials of the external urethral sphincter, anal sphincter, and bulbocavernosus muscle in normal men. Neurourol. Urodynamics., 6, 65-69, 1987.

14) Fowler, C.J., Kirby, R.S., Harrison, M.J.G., Milroy, E.J.G. and Turner-Warwick, R.: Individual motor unit analysis in the diagnosis of disorders of urethral sphincter innervation. J. Neurol. Neurosurg. Psychiatry., 47, 637-641, 1984.

15) Buchthal, F., Pinelli, P. and Rosenfalck, P.: Action potential parameters in normal human muscle and their physiological determinants. Acta Physiol. Scand., 32, 219-229, 1954.

16) Davis, L. and Khan, Z.: Significance of electromyographic changes in the external urinary sphincter. Neurourol. Urodynamics., 5 , 555-562, 1986.

（1992年10月 23 日受付, 1993年 3 月 1 日受理, 特別掲載） 